\title{
Hactivism in Turkey: The Case of Redhack
}

\author{
Burak Polat \\ Informatics PhD Student \\ Marmara University \\ aloha@burakpolat.com

\section{Cemile Tokgöz Bakıroğlu} \\ Informatics Res.Asst. \\ Marmara University \\ cemile.tokgoz@marmara.edu.tr

\section{Mira Elif Demirhan Sayın} \\ Informatics PhD Student \\ Marmara University \\ mirademirhan@gmail.com
}

\section{Doi:10.5901/mjss.2013.v4n9p628}

\section{Abstract}

Ever since daily activities have been carried into digital, cyberspace have become one of the primary grounds for citizen participation activities such political discourse and activism. Wikileaks documents, the effects of social media in the Arab Spring and global and local hacker movements are great instances for digital political participation with high impact such as the creation and diffusion of new conceptions like cyber security and cyber warfare. Internet's role in this new age activism is crucial; especially hacker movements are using Internet as a tool of resistance. Hacking activity as a political activism or hacktivism is simply an activity that making a system unworkable and acquiring and publishing information with the aim of raising public awareness. Using both mainstream and social media as a communication tool, hacker groups such as Anonymous Chaos Computer Club (CCC) and LulzSec aim to ignite activist protests from online to offline. Just like the global hacker groups, hacker groups in Turkey aim the exact same goal. Turkish hacktivists can be divided into two categories as nationalist groups who hacks websites in other countries in order to leave messages and left-wing hackers who defend the freedom of information. As the most powerful example of hactivism in Turkey, Redhack contain similar aspects. In this study, hactivism will be discussed by its ethical aspects and the center of this academic study will be the Redhack case. Following the review of literature, a quantitative research in university students is shared to observe their perspective on Redhack and hactivism.

Keywords: Activism, Online Activism, Hacktivism, RedHack

\section{Introduction}

According to United Nations' eParticipation Index (2012), Turkey's e-participation level is extremely low. This low level of e-participation in turn indicates low digital individual political expression levels. Therefore the existence of Turkish hacktivist groups such as RedHack can be considered as interesting to say the least. This very anomaly was the primary motivation of our study.

Definitions and types of activism were given in order to solidify the base of our study. Online activism and hacktivism were also defined under the umbrella of activism.

In order to understand the hacktivist movement in Turkey we chose a well known hacker group, RedHack as our case study. In the process of writing this study, Gezi Park protests kicked off and many of the protestors rapidly started following RedHack's activities as a source for obtaining news.

It must be emphasized that our survey has been diffused virally among RedHack Twitter followers causing our participant group to be mostly formed as people who support RedHack.

The survey conducted in this study aims to understand the public opinion about RedHack and if there is a relation 
between feeling sympathy towards RedHack and being displeased with current social and political situation. Additionally it aims to observe if there is a correlation between the awareness of the actions taken by RedHack and its nature as perceived by the public.

\section{Activism and Hacktivism}

Activism can be defined as any action taken deliberately in order to generate a social or political change. As defined in Oxford dictionary activism is "the policy or action of using vigorous campaigning to bring about political or social change." (Oxford Dictionary) Even though the word activism is often used synonymously with protest or dissent, activism can occur in numerous political or social orientations and in a wide range of forms. (Wikipedia)

Activism is not necessarily a good thing or a bad thing. It all depends on the cause and the actions, and a person's judgment of what is worthwhile. One person might say that a protest is a valuable defense of freedom and another person might say that it is a dangerous attack on human rights. (Martin, 2007)

Actions taken under activism can be broken down in to two main categories as nonviolent and violent actions. After examining nearly 200 different methods of nonviolent actions, researcher Gene Sharp breaks them down into three categories:

1. Nonviolent protest and persuasion

Describes methods that include formal statements, communications with a wider audience, group representations, symbolic public arts, pressures on individuals, drama and music, processions, honoring the dead, public assemblies, withdrawal and renunciation.

2. Social, economic and political noncooperation

a. Social Noncooperation

Describes methods that include ostracism of persons, noncooperation with social events, and withdrawals from the social system.

b. Economic Noncooperation

i. Economic Boycotts

Describes methods that include actions by consumers, action by workers and producers, actions by middlemen, actions by owners and management, actions by holders of financial resources, and actions by governments.

ii. The Strike

Describes methods that include symbolic strikes, agricultural strikes, strikes by special groups, ordinary industrial strikes, restricted strikes, multi-industry strikes and combination of strikes and economic closures.

c. Political Noncooperation

Describes methods that include rejection of authority, citizens' noncooperation with government, citizens' alternatives to obedience, actions by government personnel, domestic government action and international government action.

3. Nonviolent intervention

Describes methods that include psychological interventions, physical interventions, social interventions, economic interventions, and political interventions. (Sharp, 1973)

Opposed to non-violent actions, violent actions such as killing and bombing can be taken in the name of activism. On extreme ends violent actions carried out by those not authorized to do so can be named as "fighting for freedom" or terrorism. However, this is usually called armed struggle rather than activism. (Martin, 2007)

In between nonviolent and violent activism is vandalism. If done on behalf of a cause vandalism can be classified as a form of activism. Examples of vandalism include but not limited to egg throwing, property destruction and tagging. Vandalism can be praised or dispraised depending on a person's judgment.

The methods of activism keep evolving along with sociological and technological developments. Digital technologies help shaping public opinions and fast organization of actions. Online activism is the use of electronic communication technologies such as e-mail, blogs and social networking sites for a cause to enable faster communication and information transfer. Online activism uses information technologies for its cause related activities. Online activism is also referred as Internet activism, e-activism, cyber activism, etc. Online activism is also referred as Internet activism, e-activism, cyber activism, etc. (Wikipedia) 
Hacktivism is a portmanteau word of hacking and activism. As defined in Oxford Dictionary a hacker is "a person who uses computers to gain unauthorized access to data." So the term hacktivism defines hacking in order to generate a social or political change. It is carried out under the premise that proper use of technology can produce results similar to those of conventional acts of protest, activism, and civil disobedience. (Wikipedia)

There are two opposing views about the definition of hacktivism. While some see hacktivism as cyber terrorism, some see it as the efficient use of technology for affecting a social change. There is an ongoing debate on whether hacktivism is a nonviolent or a violent action in terms of activism.

\section{Hacktivism in Turkey: The Case of RedHack}

Cyber warfare raises issues of growing nation's interests. Cyber warfare can be used to describe various aspects of defending and attacking information and computer networks in cyberspace. (Hildreth, 2001) As in the world, Turkey has witnessed such attacks over the last few years. For example, The Information and Communication Technologies Authority in Turkey had been attacked after their announcement about internet filtering decision. Personal data of users, who use online services of ICTA, was disclosed. This agency, which wants to control internet communication, cannot provide its own security. Because of events such as this example, many governmental agencies came under cyberattacks. (Some of these attacks were done by Anonymous.)

The first national hacking action is actualized in October, 1998; Show TV's, a national television channels, web site has been hacked by KillRoy and WildHoney. Hackers add a long text and a mocking photograph of a famous anchorman Reha Muhtar. (Eriş, 2009)

The hacker groups of Turkey mainly divided in two. Nationalist hacker groups attack to web sites of other countries and leave messages if there is a problem about international relations. For instance, they attacked to the French parliament's web site that revived Armenian Genocide Law and leaved threatening messages. The other example of their actions is that they hacked one of communications forum of Anonymous for defending ICTA. The other claims that they obey the hacker ethics and defend the freedom of information. They are anti-authoritarian, leftist and anarchist, and RedHack is one of them.

\subsection{RedHack}

RedHack claimed that they are a Marxist-socialist group and they were founded in 1997. The core team of the group consists of twelve members. They are in cooperation with other hacker groups such as Anonymous. According to RedHack, they are not only a hacker group, in the future they will be considered as a philosophy. (Gökdemir, 2013)

\subsection{Actions of RedHack:}

\subsubsection{February 2012}

- Ankara Police Department's web page has been hacked and internal information has been leaked. This hacking action is created a strong publicity for RedHack. Police Department has taken 17 citizens under custody however RedHack declared that none of them were their members.

- $\quad$ March 2012

- To protest the violence on Turkish Public Worker Union Confederation (KESK) members, 350 police department web sites have been hacked.

- Web page of Justice and Development Party's Provincial Directorship in Sivas is hacked with adding a Smurf Father (A cartoon character) image.

- April 2012

- Web page of Fethullah Gülen (A spiritual leader for Turkish-Islam Community) has been hacked. Hammer and sickle as Communism symbols has been added with a message "Damn imam and his followers, long live revolution."

- Internal Affairs Ministry's site has been hacked and "Do a somersault if you love us." message has been added onto the site for Minister.

- TTNET (An internet service provider) has been hacked and for two hours internet connection via TTNET was blocked. 
- RedHack preannounced their attack, related governmental bodies has blocked the connection to defend the cyber-attack for two hours. RedHack declared the reason for their action:

1. To actualize the immediate release of 7 people that is claimed as members of RedHack.

2. Anonymous and RedHack works together.

3. To show the solidarity for May $1^{\text {st }}$ the Labor Day

4. To protest TTNET because of high prices with low connection speed.

5. To protest Fetullah Gülen and his followers.

6. To have fun.

\subsubsection{May - June 2012}

- Environment and Urban Planning Ministry website had been hacked to protest hydro-nuclear power plant.

- Family and Social Policies Ministry website was hacking on Mother's Day.

- After Melih Gökçek, who is a Turkish politician and has been the mayor of Ankara, shared a woman's phone number, RedHack published his and his all family's phone numbers, addresses and national identification numbers.

- The system of Turkish Land Forces was hacked and personal data of all members were published.

- They carried out a cyber-attack to website of Turkish Airlines.

- A lot of students were poisoned because of the milk distributed at schools. After that, RedHack hacked the websites of Food, Agriculture and Livestock Ministry and milk producers won tender.

- RedHack hacked website of National Intelligence Organization when the organization was deployed against them.

\subsubsection{July 2012}

- RedHack attacked to website of Foreign Affairs Ministry, and published foreign diplomats' personal data via Dropbox. After that twitter account of RedHack was closed with the suppression of USA.

- Student Selection and Placement Center's website was hacked.

- They hacked the website of Justice and Development Party and leaved messages.

- Redhack claimed that academicians and journalists, who support their actions, were under threat. Because of that, they published all of the documents obtained Ankara Police Department.

- The Facebook page of Turkish Radio and Television Corporation had been hacked.

\subsubsection{August 2012}

- After the release of child rapists, RedHack hacked the websites of Supreme Court and Constitutional Court.

\subsubsection{September 2012}

- While waiting the decision of Governorship of Sinop about nuclear power plant, their website had been hacked and a message leaved: "Nuclear power plant is fascism!"

\subsubsection{November 2012}

- RedHack supported Anonymous on Hack operations against Israel.

- Public Auction Corporation's web site was hacked with adding a disinformation into the announcement such as pricing JDP with 1 Turkish Lira.

\subsubsection{December 2012}

- Several social network accounts with child abuse videos were hacked and closed. 


\subsubsection{January 2013}

- Higher Education Corporation's web page was hacked.

- Corruption documents of several universities were leaked.

\subsubsection{February 2013}

- Documents about Ankara Municipality President, Melih Gökçek, are leaked.

- March-April 2013

- Web page of Ankara Municipality had been hacked.

- MOSSAD's site is hacked with cooperation of Anonymous.

- Israeli diplomats' and bureaucrats' personal information is publicly shared.

- May 2013

- Because of the terrorist attack in Reyhanlı, RedHack hacked Hatay Governorship's site to declare they demand a national mourning.

- Turkish Intelligence documents on Reyhanlı had leaked by RedHack.

\subsubsection{June 2013}

- RedHack hacked the website of Beyoğlu Police Department to protest Gezi Park.

- RedHack claimed responsibility for all tweets that were posted about the Taksim Gezi Park protests after the government announced that an investigation into the matter had been launched. (Hürriyet Daily News, 2013)

- After Ethem Sarısülük's death, who was shot in the head and killed by the police during the protest in the capital Ankara, websites of Ankara Police Department and Governorship of İstanbul were hacked by RedHack.

- $\quad$ After Abdullah Cömert's death, who died during the protest in Hatay, website of Governorship of Hatay was hacked by RedHack.

- After Mehmet Ayvalıtaş's death, who died during the protest, website of İstanbul Police Department was hacked by RedHack.

\section{Survey Results}

The survey was designed to measure 4 factors. The first factor aims to measure the demographics of participants. The second factor intends to understand the social and political opinions and contentedness on Turkey. The third factor aims to measure the knowledge of the participants about Redhack. The last factor plans to understand the approach of the participants to the actions taken by RedHack.

\subsection{Demographics}

Out of 1804 people who participated in our survey $57 \%$ is male. $65 \%$ of the participants are between the ages of $18-29$, the rest of the participants are distributed among the age groups as $17 \%$, between the ages of $30-34,15 \%$ above 35 and $4 \%$ under $18.81 \%$ of all participants are either still studying in a university or higher education or graduated from a university or higher education. Of the people who have participated $45 \%$ are students while $15 \%$ are employed in private corporations and $14 \%$ are business owners. The remaining $16 \%$ is made of government employees and retired or unemployed citizens. Participation from Istanbul is the highest with $47 \%$ followed by Izmir, Ankara and foreign countries with the rates of $11 \%, 10 \%$ and $7 \%$ respectively. The rest $25 \%$ is distributed among different cities of Turkey with low percentages.

\subsection{Social and Political Opinions}

Participants' answers on statements on how and from where RedHack got support shows that vast majority of the participants believe that there is no one behind RedHack but RedHack's itself. $2 \%$ of the participants believe strictly that Turkish Government is supporting RedHack, 8\% believe that a Foreign Government or a foreign organization gives 
support and \%4 of the participants believe RedHack has a strong relationship with Terrorist Groups. \%21 of the overall participants are not sure about if RedHack got support from a foreign government or a foreign organization or not, should be emphasized.

Because of the vast majority of participants have a positive opinion on RedHack; survey analysis is divided into two as RedHack supporters and non-supporters to observe possible divergences with comparing survey responses of these two groups. This division was based on the answers given to the question "Do you support the activities of RedHack?".

The main divergences observed are:

- Gender distribution of supporters are 56\% male and 44\% female however non-supporters' gender distribution is $65 \%$ male and $35 \%$ female.

- $\quad$ There are $10 \%$ more students in supporters.

In Table 1 non-supporters/not sure are shown as "Group A" and supporters are shown as "Group B" to present the responses of participants on socio-political status of Turkey.

Table 1. The responses of participants on socio-political status of Turkey

\begin{tabular}{|c|c|c|c|}
\hline \multicolumn{2}{|l|}{ Socio-political expressions about Turkey. } & Group A & Group B \\
\hline \multirow{3}{*}{ I believe that I have freedom of expression. } & Disagree & 65.1 & 81.9 \\
\hline & Neutral & 12.8 & 6.6 \\
\hline & Agree & 22.1 & 11.5 \\
\hline \multirow{3}{*}{ I think that Turkey has good economic conditions. } & Disagree & 60.4 & 83.8 \\
\hline & Neutral & 17.4 & 11.4 \\
\hline & Agree & 22.2 & 4.8 \\
\hline \multirow{3}{*}{ I trust judicial system. } & Disagree & 77.0 & 94.1 \\
\hline & Neutral & 11.5 & 4.5 \\
\hline & Agree & 11.5 & 1.4 \\
\hline \multirow{3}{*}{ I think that democracy level is high enough in Turkey. } & Disagree & 78.5 & 97.4 \\
\hline & Neutral & 8.7 & 1.3 \\
\hline & Agree & 12.8 & 1.3 \\
\hline \multirow{3}{*}{ I trust in executive and legislative in Turkey. } & Disagree & 74.5 & 97.2 \\
\hline & Neutral & 12.1 & 2.1 \\
\hline & Agree & 13.4 & 0.7 \\
\hline \multirow{3}{*}{ I trust news on TV and newspapers. } & Disagree & 88.5 & 96.8 \\
\hline & Neutral & 8.1 & 2.1 \\
\hline & Agree & 3.4 & 1.1 \\
\hline \multirow{3}{*}{ I believe that I am being represented in parliament. } & Disagree & 74.1 & 93.0 \\
\hline & Neutral & 11.6 & 5.0 \\
\hline & Agree & 14.3 & 2.0 \\
\hline \multirow{3}{*}{ I am satisfied with the public services. } & Disagree & 54.4 & 74.2 \\
\hline & Neutral & 18.8 & 19.2 \\
\hline & Agree & 26.8 & 6.6 \\
\hline \multirow{3}{*}{ I believe that the government is transparent. } & Disagree & 75.2 & 98.1 \\
\hline & Neutral & 10.7 & 0.9 \\
\hline & Agree & 14.1 & 1.1 \\
\hline \multirow{3}{*}{ I think that the government is reliable. } & Disagree & 73.0 & 98.6 \\
\hline & Neutral & 10.1 & 0.8 \\
\hline & Agree & 16.9 & 0.6 \\
\hline \multirow{3}{*}{ I believe that the judiciary is independent. } & Disagree & 76.4 & 96.9 \\
\hline & Neutral & 11.8 & 2.3 \\
\hline & Agree & 11.8 & 0.8 \\
\hline \multirow{3}{*}{ I am optimistic about the future of Turkey. } & Disagree & 47.3 & 64.5 \\
\hline & Neutral & 23.6 & 23.5 \\
\hline & Agree & 29.1 & 12.0 \\
\hline
\end{tabular}


- There are 10\% more participants in Group A believes that freedom of expression level is sufficient.

- Main-stream media trust level is considerably low for both groups. It can be emphasized low media trust levels creates a strong convergence for both groups.

- Only $1.3 \%$ of Group B believes that democracy level is insufficient and $12.8 \%$ of Group A believes that democracy level is sufficient.

- JDP's transparency and accountability level is sufficient for $0.85 \%$ in Group B and for $15.5 \%$ in Group A.

- Neutral responses on future of Turkey for both groups are very similar for both groups; $23.6 \%$ for Group A, 23.5\% for Group B. RedHack supporters are unhappy about that future of Turkey.

- There is a considerable amount of participants that are optimistic about the future of Turkey and public services' quality. It must be emphasized that RedHack supporters are tend to be pessimistic about the future of Turkey and public services' quality.

- Economic development level, Freedom of Expression, Optimism in the future of Turkey and the quality of public services have more affirmative responses for both groups, according to the other survey questions.

\subsection{Recognition of Actions Taken by RedHack}

As stated before the third factor aims to measure recognition degree of participants about the actions of RedHack.

\section{For how long have you known about the existance of RedHack?}

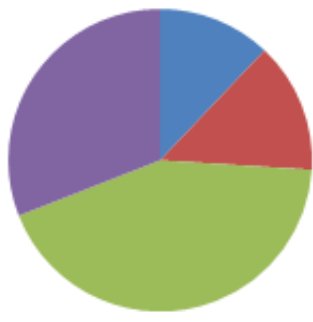

\section{Where did you first hear about} RedHack?

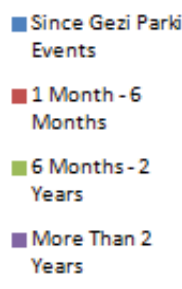

According to the participants, RedHack's is best known for their infamous activities in which they choose their targeted websites based on specific objectives, revealing secret data normally unavailable to public and crippling or outright disabling certain organizations including but not limited to those which belong to the government.

If the three most widely known activities listed above are excluded from the statistics, it appears that $45 \%$ of the participants have accurate knowledge about the actions of RedHack while $37 \%$ stated that they have no knowledge at all. The remaining $18 \%$ consists of participants who answered the questions inaccurately. The most popular of these answers are:

- RedHack does not attack private corporations' websites

- RedHack only acts within Turkey

...none of which are correct.

In table 2 Responses on RedHack activities are shown for Group A and B.

Table 2. The responses of participants on RedHack activities

\begin{tabular}{|c|c|c|c|}
\hline \multicolumn{2}{|c|}{ Expressions about actions of RedHack } & Group A & Group B \\
\hline \multirow{2}{*}{$\begin{array}{c}\text { I believe that the accuracy of the information shared by } \\
\text { RedHack. }\end{array}$} & Disagree & 40.5 & 0.5 \\
\cline { 2 - 4 } & Neutral & 21.0 & 2.8 \\
\cline { 2 - 4 } & Agree & 38.5 & 96.7 \\
\hline \multirow{2}{*}{ I see RedHack as a news source. } & Disagree & 47.6 & 1 \\
\cline { 2 - 4 } & Neutral & 21.1 & 4.8 \\
\cline { 2 - 4 } & Agree & 31.3 & 94.2 \\
\hline
\end{tabular}




\begin{tabular}{|c|c|c|c|}
\hline \multirow{3}{*}{ I believe that RedHack should share information. } & Disagree & 48.3 & 2 \\
\hline & Neutral & 21.4 & 2.4 \\
\hline & Agree & 30.3 & 95.5 \\
\hline \multirow{3}{*}{ I think that actions of RedHack are illegal. } & Disagree & 36.5 & 72.1 \\
\hline & Neutral & 29.7 & 16.3 \\
\hline & Agree & 33.8 & 11.6 \\
\hline \multirow{3}{*}{ I think that actions of RedHack are extreme. } & Disagree & 55.1 & 93.5 \\
\hline & Neutral & 24.5 & 3.8 \\
\hline & Agree & 20.4 & 2.7 \\
\hline \multirow{3}{*}{$\begin{array}{l}\text { I get disturbed when RedHack hacks the websites that I use in } \\
\text { my daily life. }\end{array}$} & Disagree & 62.3 & 91.2 \\
\hline & Neutral & 12.4 & 5.7 \\
\hline & Agree & 25.3 & 3.1 \\
\hline \multirow{3}{*}{ I believe that RedHack has many supporters. } & Disagree & 45.5 & 5 \\
\hline & Neutral & 22.1 & 10.8 \\
\hline & Agree & 32.4 & 84.3 \\
\hline \multirow{3}{*}{ I think that RedHack is supported by the government. } & Disagree & 77.6 & 94.7 \\
\hline & Neutral & 15.0 & 3.9 \\
\hline & Agree & 7.4 & 1.4 \\
\hline \multirow{3}{*}{ I think that RedHack is supported by the external sources. } & Disagree & 45.9 & 73.0 \\
\hline & Neutral & 28.4 & 20.1 \\
\hline & Agree & 25.7 & 6.9 \\
\hline \multirow{3}{*}{ I think that RedHack is supported by the terrorist groups. } & Disagree & 60.5 & 90.5 \\
\hline & Neutral & 19.1 & 7.3 \\
\hline & Agree & 20.4 & 2.1 \\
\hline \multirow{3}{*}{ I believe that actions of RedHack are well-intentioned. } & Disagree & 38.8 & 1.9 \\
\hline & Neutral & 25.2 & 3.2 \\
\hline & Agree & 36 & 94.9 \\
\hline \multirow{3}{*}{ I think that the government takes RedHack seriously. } & Disagree & 45.9 & 12.8 \\
\hline & Neutral & 24.0 & 21.3 \\
\hline & Agree & 30.1 & 65.9 \\
\hline \multirow{3}{*}{ I believe that RedHack is impartial. } & Disagree & 61.1 & 23.3 \\
\hline & Neutral & 20.1 & 15.4 \\
\hline & Agree & 18.8 & 61.3 \\
\hline \multirow{3}{*}{ I think that RedHack will create a change. } & Disagree & 50.3 & 3.9 \\
\hline & Neutral & 31.7 & 18.3 \\
\hline & Agree & 18 & 77.8 \\
\hline \multirow{3}{*}{ I believe that the aim of RedHack is to obtain transparency. } & Disagree & 41.7 & 1.6 \\
\hline & Neutral & 21.5 & 6 \\
\hline & Agree & 36.8 & 92.4 \\
\hline \multirow{3}{*}{ I believe that the aim of RedHack is to obtain awareness. } & Disagree & 39.6 & 9.4 \\
\hline & Neutral & 11.8 & 4.8 \\
\hline & Agree & 48.6 & 85.8 \\
\hline \multirow{3}{*}{ I believe that the aim of RedHack is to punish. } & Disagree & 31.7 & 11.5 \\
\hline & Neutral & 21.4 & 10.4 \\
\hline & Agree & 46.9 & 78.1 \\
\hline \multirow{3}{*}{ RedHack is an activist group. } & Disagree & 35 & 6.8 \\
\hline & Neutral & 20.2 & 13.1 \\
\hline & Agree & 44.2 & 80.4 \\
\hline \multirow{3}{*}{ I think that number of groups such as RedHack should increase. } & Disagree & 47.6 & 10 \\
\hline & Neutral & 33.1 & 16.5 \\
\hline & Agree & 19.3 & 73.5 \\
\hline \multirow{3}{*}{ Actions of RedHack are good for independence. } & Disagree & 42.4 & 0.9 \\
\hline & Neutral & 19.4 & 2.1 \\
\hline & Agree & 38.2 & 97 \\
\hline \multirow{3}{*}{ RedHack is an opposing group. } & Disagree & 32.6 & 15.1 \\
\hline & Neutral & 23.6 & 13.9 \\
\hline & Agree & 43.8 & 71 \\
\hline
\end{tabular}


RedHack is a terrorist group.

\begin{tabular}{|c|c|c|}
\hline Disagree & 67.6 & 96.4 \\
\hline Neutral & 16.6 & 2.3 \\
\hline Agree & 15.9 & 1.3 \\
\hline
\end{tabular}

According to table above;

- More than $90 \%$ of the Group B trust the information shared by RedHack, do not find RedHack activities extreme, do not mind if a website is down, do not believe any government or an organization gives support, believe that RedHack is favorable, believe that RedHack is trying to obtain transparency, believe RedHack supports freedom and believes that Redhack is not a terrorist group.

- $\quad 65.9 \%$ of Group B believes that Turkish Government does not take RedHack serious.

- $\quad 61.3 \%$ of Group B and $61.1 \%$ of Group A state that RedHack is neutral.

- RedHack describes itself as an illegal organization however only $11.6 \%$ of the Group B and $33.8 \%$ of Group A believes that RedHack is illegal.

- $\quad 15.9 \%$ of Group A and $1.3 \%$ of Group B believes that RedHack is a terrorist group.

- $\quad 77.6 \%$ of Group A does not believe that RedHack is supported by Turkish government.

- Group A believes that RedHack's actions will not create a change, RedHack should not share classified documents and RedHack should be seen as an information source; and also Group A believes that RedHack's activities are not extreme and RedHack can create strong awareness on certain issues.

- $65 \%$ of the Group B believes that government takes RedHack serious and $61 \%$ of the same group states that RedHack is politically neutral.

\section{Conclusion}

Low levels of electronic participation in Turkey cause a low amount of digital political expression. In the presence of a public which is largely non-reactive to political issues, RedHack attains a great value with its digital yet illegal activities. Gezi protests, especially, show that suppressed expressions of the public can create an extreme and instant reaction directed towards the authorities. Protestors believe that all governmental bodies and main-stream media turned their back to them and in this conjuncture RedHack's actions created sympathy within the public.

Gezi protests have transformed the image and raised the level of awareness of RedHack. For a considerable amount of people, RedHack became more of a freedom fighter rather than a hacktivist group. It must be emphasized that our survey has been diffused virally among RedHack Twitter followers. Our survey showed that RedHack supporters strongly believe that governmental bodies are not working efficiently and mass-media is ignoring or manipulating the truth. For them, RedHack is an information source and a strong opposing power without any form of support from any government and organization.

As an extreme type of digital activism, globally, hacktivism has a great role on shaping political stance of the public. Just like it's globally, each passing day, hacktivist groups' importance is increasing in Turkey too. And although the ideologies and activities of Hacktivist groups' are open to debate, their impact - without a doubt- is unquestionable.

\section{References}

Eriş, U. (2009). Türkiye'de kırııı (hacker) kültürü. Eskişehir, Türkiye: Anadolu Üniversitesi.

Gökdemir, O. (2013). RedHack: Sanal Alemin Klavyeli Asileri. İstanbul: Destek Yayınları.

Hildreth, S. A. (2001). CRS Report for Congress.

Hürriyet Daily News. (2013, June 20). www.hurriyetdailynews.com.Retrieved June 26, 2013, from Hürriyet Daily News: http://www.hurriyetdailynews.com/turkish-hacker-group-redhack-claims-responsibility-for-all-tweets-about-geziprotests.aspx?pagelD=238\&nID=49137\&NewsCatID=341

Martin, B. (2007). Activism, social andpolitical. G. L. Anderson, \& K. G. Herr, Encyclopedia of Activism and Social Justice (19-27). Thousand Oaks, CA: Sage.

Oxford Dictionary. (2013). Retrieved 06 08, 2013, from Oxford Dictionary: http://oxforddictionaries.com/definition/english/activism

Sharp, G. (1973). The Methods of Nonviolent Action (The Politics of Nonviolent Action \#1). Boston: Porter Sargent Publishers.

United Nations. (2012). E-Government Survey 2012: E-Government fot the People. New York: United Nations.

Wikipedia. (2013). Retrieved 06 07, 2013, from Wikipedia.org: http://en.wikipedia.org/wiki/Activism

Wikipedia. (2013). Retrieved June 10, 2013, from Wikipedia.org: http://en.wikipedia.org/wiki/Hacktivism

Wikipedia. (2013). Retrieved 06 06, 2013, from Wikipedia.org: http://en.wikipedia.org/wiki//nternet_activism 